\title{
Formação e profissionalização de professores da educação infantil
}

\section{Early childhood teacher preparation and professionalization}

Zilma de Moraes Ramos de Oliveira é pedagoga e doutora em Psicologia pela Universidade de São Paulo (USP), professora associada (aposentada) da Faculdade de Filosofia, Ciências e Letras de Ribeirão Preto da USP, coordenadora do curso de especialização em Gestão Pedaǵógica e Formação em Educação Infantil do Instituto Superior de Educação Vera Cruz (ISE Vera Cruz) e assessora de redes públicas de ensino na área de educação infantil.

Contato: zilmaoliveira@uol.com.br

\section{Resumo}

0 texto discute como tem sido historicamente definido o papel do professor que trabalha com crianças de 0 a 5 anos em instituições brasileiras de educação infantil. Além disso, analisa o modo como as concepções atribuídas a tais instituições implicam diferentes posições em relação à formação inicial e continuada do professor e à presente possibilidade de sua profissionalização nas redes de ensino. Palavras-chave: professor da educação infantil; formação docente; profissionalização docente.

\section{Abstract}

The article discusses the role of the teacher in Brazilian daycare centers and pre-schools related to how these institutions have been dynamically conceived and the impact of these conceptions on teachers' initial training and professionalization.

Keywords: early childhood teacher; teachers' preparation; teachers' professionalization. 
Apesar da relativamente recente inclusão da educação de crianças de 0 a 5 anos nos sistemas de ensino - compondo o nível chamado de educação infantil -, diferentes posições têm sido levantadas em relação ao profissional que seria responsável pelas crianças nesses sistemas. Cada vez mais se fortalece a compreensão de que, no sistema de ensino, o profissional responsável pela educação da criança é o docente (vide Lei ${ }^{\circ}$ 9.394/96, artigo 13), tal como ocorre em outros níveis de ensino, ou seja, alguém técnica e legalmente habilitado para educar crianças dessa faixa etária.

Isso contraria posicionamentos sobre o tema que não pressupõem um preparo sistematizado do profissional e que, quando o fazem, não consideram que esse preparo deve guiar-se por normas referentes ao magistério. Ao contra-argumentar em relação a tais posições, devemos ressaltar que, nos últimos trinta anos, o conhecimento científico sobre a educação, a aprendizagem e o desenvolvimento de crianças pequenas tem avançado muito, provocando impacto nos diferentes países em relação ao aprimoramento da educação infantil.

No Brasil, a presença de educadores leigos trabalhando junto às crianças em pré-escolas e creches ainda é muito grande. Além disso, o nível de escolaridade dos profissionais que atuam na educação infantil é mais baixo do que o nível de escolaridade daqueles que trabalham nos demais níveis de ensino. Isso tem levado à discussão da necessidade de se eliminar a presença de leigos na educação infantil e as formas diversas de enquadramento profissional e de contratação por redes de ensino que consideram como profissionais da educação auxiliares de desenvolvimento infantil, técnicos em desenvolvimento infantil, recreacionistas, monitores, pajens e outras denominações. Para bem encaminhar essa reflexão, temos de rever o que se entende por identidade da educação infantil e por profissionais da educação, bem como pensar a formação de profissionais da educação infantil.

É preciso considerar que a formação profissional dos educadores que trabalham na educação infantil é um processo cultural que depende da função atribuída à creche e à préescola. Historicamente, tal formação, principalmente dos educadores que trabalham com crianças menores de 3 anos, está fundamentada em uma concepção de cuidado infantil como processo naturalizado que se aprende e se desenvolve no processo de instituição da parentalidade, sobretudo das funções maternas, e que se dá não em uma instituição educacional, mas em contexto domiciliar e comunitário. Isso tem gerado muita 
atuação leiga, predominantemente feminina. Também é muito recente conceber a educação de crianças menores de 6 anos como tarefa dos sistemas de ensino, estes mais preocupados em garantir o aprendizado da alfabetização e de noções básicas das chamadas disciplinas escolares (Barreto, 1994; Ongari; Molina, 2003).

Para acompanharmos alguns debates que circulam em nossa sociedade, vamos examinar três dos argumentos que têm sido apresentados para defender que a presença de um professor é desnecessária, ou secundária, em se tratando da educação de crianças de até 3 anos:

Respondendo ao argumento 1: Para atender e educar criança pequena, basta ser mulher, não é preciso uma formação específica.

A concepção assistencialista tradicionalmente usada para orientar o atendimento às crianças de famílias de baixa renda em creches fez com que fossem admitidas para trabalhar nesses locais pessoas sem qualificação profissional específica, em uma concepção de que bastaria a experiência de cuidado dos próprios filhos. Considerando suficiente a transposição de competências maternais para orientar o trabalho com o grupo de crianças, desse profissional eram esperadas paciência, capacidade para se relacionar afetivamente com as crianças e firmeza na condução do grupo infantil.

Entretanto, um olhar mais aprofundado à questão revela que a condição de ser mulher não é aceita quando se trata de atender crianças das camadas sociais de melhor renda. Essas famílias e as unidades educacionais que as atendem há muito defendem que o foco de seu trabalho é educacional, e não assistencial.

De modo a garantir equidade no tratamento das crianças dos diferentes grupos sociais, tem-se que não apenas admitir a articulação e a indissociação das tarefas de educar e cuidar, como também reconhecer que a efetividade dessas tarefas requer que as ações fiquem a cargo de alguém cuja formação profissional exig’e que sejam trabalhados certos conhecimentos específicos, ou seja, conhecimentos próprios de um professor.

É certo que, além de sujeitos de aprendizagem em determinada etapa de seu desenvolvimento e em determinada cultura, as crianças são dependentes da ajuda de um parceiro adulto para o atendimento individualizado de suas necessidades de proteção, afeto, higiene, alimentação, sono etc. Contudo, se a meta é 
garantir atendimento a necessidades e desejos das crianças e respeito aos seus direitos, o risco é pensá-la ligada à satisfação apenas de necessidades físicas (o que já seria meio caminho andado) e a experiências pouco exigentes, no sentido de pouco desafiadoras, para as crianças.

Garantir o bem-estar refere-se a atributos dinâmicos e deve perpassar o conjunto das decisões pensadas para as crianças, os professores e os familiares em relação ao planejamento das situações de convivência, aprendizagem e desenvolvimento. Há, portanto, conteúdos específicos na formação do professor que atua na creche.

0 professor de crianças de 0 a 3 anos de idade deve ser um especialista e sua formação, oferecida nos cursos de graduação, especialização e na formação continuada, deve possibilitar a esse profissional lidar com a organização dos espaços e dos tempos das unidades (os estabelecimentos) de educação infantil e com as dinâmicas dos grupos infantis, com foco em diferentes prioridades: cuidado físico, atividades propostas para ocorrerem em grupo ou individualmente que possibilitam a construção, pela criança, de significações sobre o mundo e sobre si.

Respondendo ao argumento 2: Criança pequena não está pronta para aprender e, assim, não precisa de um professor.

Essa concepção, muitas vezes defendida por um olhar leigo, é superada quando se pensa que a educação de crianças de 0 a 3 anos em estabelecimentos educacionais, deve considerar que essa fase é constitutiva do processo de se tornar humano, o qual se dá na relação com o outro. Em outras palavras, a criança, desde o nascimento, interage com parceiros diversos que lhe ajudam a significar o mundo e a si mesma, a realizar um número crescente de diferentes aprendizagens e a constituir-se como um ser histórico singular.

Ora, se desde o nascimento já estão presentes processos de aprendizagem, estes requerem uma atenção especial quando ocorrem no contexto de uma instituição de educação coletiva de crianças, que é diferente do contexto familiar e requer habilidades próprias de quem trabalha com as crianças em relação ao planejamento dos ambientes, às atitudes e aos procedimentos que compõem os cuidados com alimentação, higiene, conforto, proteção e estímulos a brincadeiras.

Nas instituições de educação infantil, o professor tem de 
responder à especificidade das características das crianças e atuar como um mediador especial, como um recurso de que elas dispõem para aprender a realizar diferentes ações e desenvolverse, ou seja, ampliar sua forma de agir, sentir e pensar. No decorrer das interações que estabelece com elas, o professor busca ser sensível às suas necessidades e aos seus desejos, fortalecer as relações que elas estabelecem entre si e preocupar-se em envolvê-las em atividades significativamente variadas, a serem realizadas com diferentes recursos.

A mediação do professor se faz à medida que ele busca familiarizar a criança com significações historicamente elaboradas para orientar as pessoas a como agir e compreender as situações e os elementos do mundo. 0 professor age de uma forma indireta, pelo arranjo do contexto de aprendizagem das crianças: os espaços, os objetos, os horários, os agrupamentos infantis. Mas, em especial, ele atua de modo direto conforme interage com as crianças, apresenta-lhes modelos, considera suas reações durante a troca, as refeições, as brincadeiras e outras explorações, responde ao que elas perguntam, faz perguntas para conhecer suas respostas, pega-as no colo quando se emocionam e, por vezes, opõe-se ao que elas estabelecem para ajudá-las a ampliar o olhar, ensinar-Ihes as regras de seu grupo social ou aperfeiçoar seu modo de sentir as situações, tudo isso desde muito cedo.

As ações do professor junto às crianças são cultural e historicamente constituídas e baseiam-se, em especial, na representação que ele faz de seu papel e na concepção de criança e de educação infantil que possui. Daí a importância de o professor centrar seu olhar na criança e vê-la como parceira ativa, dona de um modo próprio de significar o mundo e a si mesma, ponto que reformula certas concepções que veem o ensino como um movimento que parte do professor e que tomam a criança como mero receptor de suas mensagens. Essas novas representações e concepções devem ser apropriadas pelo professor em sua formação profissional.

Para dar visibilidade ao processo de desenvolvimento das crianças, o professor precisa aprender a documentar situações por meio de registros diários, a refletir sobre suas práticas pedagógicas de modo a identificar e traduzir os sinais das crianças e, a partir disso, a organizar o cotidiano infantil.

Respondendo ao argumento 3: Criança pequena precisa é de alguém para trocá-la e supervisioná-la ao brincar. 0 professor só necessita trabalhar com ela nos momentos destinados às 
atividades pedagógicas.

0 modelo higienista de atendimento em instituições como creches e parques infantis defende a presença de pessoas capazes de dar atenção ao desenvolvimento físico das crianças e privilegia o aprendizado pelo cuidador de noções de higiene, nutrição e primeiros socorros. Já uma concepção recreacionista da educação infantil enfatiza a presença de animadores culturais - por vezes, agentes da comunidade - junto às crianças para ocupá-las em seu tempo livre.

Entretanto, os pesquisadores que estudam o desenvolvimento e a educação de bebês afirmam que momentos de sono, alimentação e convivência em pequenos grupos constituem situações importantes de aprendizagem, desenvolvimento e constituição da pessoa.

Concluindo, o que já se tem como conhecimento acumulado sobre educação e cuidado de crianças de até 3 anos em instituições tipo creche evidencia que essas tarefas, por ocorrerem em um ambiente diverso do familiar, precisam de planejamento, desenvolvimento e avaliação das situações aí vividas pelas crianças, funções estas a serem exercidas por alguém com uma formação específica: o professor.

A formação desse docente deve ser objeto de muita pesquisa e investimento, a fim de garantir às famílias que seus filhos estão tendo seu direito a uma educação infantil de qualidade garantido, com reflexos positivos para outras esferas de sua vida cultural, escolar e pessoal.

\section{0 que diz a legislação?}

A Lei n 9.394/96, Lei de Diretrizes e Bases da Educação Nacional (LDB), ao tratar das instituições que integram o sistema de ensino, declara que a ação pedagógica é tarefa de docentes, e isso inclui a educação infantil. Já o artigo 62 da referida Lei especifica:

\footnotetext{
A formação de docentes para atuar na Educação Básica far-se-á em nível superior, em curso de licenciatura, de graduação plena em universidades e institutos superiores de educação, admitida como formação mínima para o exercício do magistério na Educação Infantil e nas quatro primeiras séries do Ensino Fundamental a oferecida em nível médio, na modalidade Normal (Brasil, 1996).
} 
De acordo com o artigo 29 da LDB, a educação infantil tem como finalidade o desenvolvimento integral da criança de 0 a 5 anos de idade em seus aspectos físicos, afetivos, intelectuais, linguísticos e sociais, complementando a ação da família e da comunidade. A fim de alcançar resultados mais promissores, de acordo com a produção científica da área, esse paradigma do desenvolvimento integral da criança, a ser necessariamente compartilhado com a família, deve efetivar-se considerando as formas como ela, desde o nascimento, vivencia o mundo, constrói significação e conhecimentos, expressa-se, interage com diferentes parceiros, manifestando desejos e curiosidades de modos bastante peculiares (Brasil, 2009a).

Uma rede de ensino pode contratar nutricionistas, além de psicólogos, fonoaudiólogos etc., profissionais de nível superior graduados em áreas distintas do magistério para trabalhar na educação infantil, conforme a disponibilidade de seus recursos financeiros. Contudo, é exigida formação - no mínimo, de nível médio na modalidade Normal - dos recreacionistas ou profissionais com outras denominações contratados para trabalhar com as crianças.

\section{Conclusão}

Já existem argumentos suficientes para se interpretar a Lei $n^{\circ}$ 9.394/96 e afirmar que todos os profissionais responsáveis pelas turmas de crianças pequenas em creches, pré-escolas ou entidades equivalentes devem ser professores com formação específica em educação infantil, responsáveis e conscientes da importância de todas as atividades pelas quais se responsabilizam, inclusive trocas, alimentação, higiene etc.

Na formação desse profissional, deve-se considerar o que dispõe o Parecer CNE/CEB n 20/09, que trata das Diretrizes Curriculares Nacionais para a Educação Infantil:

\footnotetext{
As instituições de Educação Infantil devem assegurar a educação em sua integralidade, entendendo o cuidado como algo indissociável ao processo educativo.

As práticas pedagógicas devem ocorrer de modo a não fragmentar a criança nas suas possibilidades de viver experiências, na sua compreensão do mundo feita pela totalidade de seus sentidos, no conhecimento que constrói na relação intrínseca entre razão e emoção, expressão corporal
} 
e verbal, experimentação prática e elaboração conceitual. As práticas envolvidas nos atos de alimentar-se, tomar banho, trocar fraldas e controlar os esfíncteres, na escolha do que vestir, na atenção aos riscos de adoecimento mais fácil nessa faixa etária, no âmbito da Educação Infantil, não são apenas práticas que respeitam o direito da criança de ser bem atendida nesses aspectos, como cumprimento do respeito a sua dignidade como pessoa humana. Elas são também práticas que respeitam e atendem ao direito da criança de apropriar-se, por meio de experiências corporais, dos modos estabelecidos culturalmente de alimentação e promoção de saúde, de relação com o próprio corpo e consigo mesma, mediadas pelas professoras e professores, que intencionalmente planejam e cuidam da organização dessas práticas.

A dimensão do cuidado, no seu caráter ético, é assim orientada pela perspectiva de promoção da qualidade e sustentabilidade da vida e pelo princípio do direito e da proteção integral da criança. o cuidado, compreendido na sua dimensão necessariamente humana de lidar com questões de intimidade e afetividade, é característica não apenas da Educação Infantil, mas de todos os níveis de ensino. Na Educação Infantil, todavia, a especificidade da criança bem pequena, que necessita do professor até adquirir autonomia para os cuidados de si, expõe de forma mais evidente a relação indissociável do educar e cuidar nesse contexto. A definição e o aperfeiçoamento dos modos como a instituição organiza essas atividades são partes integrantes de sua proposta curricular e devem ser realizados sem fragmentar ações.

Um bom planejamento das atividades educativas favorece a formação de competências para a criança aprender a cuidar de si. No entanto, na perspectiva que integra o cuidado, educar não é apenas isto. Educar cuidando inclui acolher, garantir a segurança, mas também alimentar a curiosidade, a ludicidade e a expressividade infantis.

Educar de modo indissociado do cuidar é dar condições para as crianças explorarem o ambiente de diferentes maneiras (manipulando materiais da natureza ou objetos, observando, nomeando objetos, pessoas ou situações, fazendo perguntas etc.) e construírem sentidos pessoais e significados coletivos, à medida que vão se constituindo como sujeitos e se apropriando de um modo singular das formas culturais de agir, sentir e pensar. Isso requer do professor ter sensibilidade e delicadeza no trato de cada criança, e assegurar atenção especial conforme as necessidades que identifica nas crianças (Brasil, 2009a).

Hoje, os pesquisadores em didática e os formadores de professores em cursos de graduação, especialização e em programas de formação continuada estão desafiados a relerem suas concepções de ensino à luz do que hoje já se conhece sobre a educação de bebês em ambiente coletivo. Da mesma forma, há que se rever e aprofundar os conhecimentos sobre a organização 
e a operacionalização dos cuidados com higiene, alimentação e bem-estar dos bebês em ambientes de educação coletiva, sem copiar os modelos domésticos ou dos serviços de saúde, que são contextos com outras características e outros objetivos (Oliveira, 2001).

Tais tarefas, sem dúvida, abrem outras oportunidades para a educação de nossas crianças!

\section{REFERÊNCIAS}

BARRETO, Ângela M. R. Por que e para que uma política de formação do profissional de educação infantil? In: MEC/ SEF/COEDI. Por uma política de formação do profissional de Educação Infantil. Brasília: MEC/SEF/COEDI, 1994. p. 11-15.

BRASIL. Presidência da República. Lei n 9.394, de 20 de dezembro de 1996. Estabelece as diretrizes e bases da educação nacional. Diário Oficial da União, Brasília, 23 dez. 1996.

Conselho Nacional de Educação. Parecer CNE/CEB n²0, de 11 de novembro de 2009. Revisão das diretrizes curriculares nacionais para a educação infantil. Diário Oficial da União, Brasília, 9 dez. 2009a.

Conselho Nacional de Educação. Resolução CNE/ CEB nº5, de 17 de dezembro de 2009. Fixa as diretrizes curriculares nacionais para a educação infantil. Diário Oficial da União, Brasília, 18 dez. 2009b.

ONGARI, Bárbara; MOLINA, Paola. A educadora de creche: construindo suas identidades. São Paulo: Cortez, 2003.

OLIVEIRA, Zilma M. R. Educação infantil: fundamentos e métodos. São Paulo: Cortez, 2001. 